Journal of Agricultural Sciences
(Tarim Bilimleri Dergisi)

\title{
Historic Landscape Characterization in Protected Areas; A Case Study Kazdagı National Park
}

\author{
Seyma SENGUR ${ }^{\mathrm{a}} \mathbb{D}$, Engin NURLU ${ }^{\mathrm{b}}$

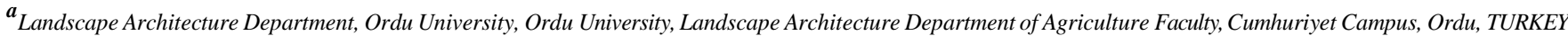 \\ ${ }^{b}$ Landscape Architecture Department, Ege University, Ege University Landscape Architecture Department of Agriculture Faculty, Izmir, TURKEY
}

ARTICLE INFO

Research Article

Corresponding Author: Seyma SENGUR, E-mail: seyma_sengur@hotmail.com

Received: 17 July 2019 / Revised: 02 December 2019 / Accepted: 12 December 2019 / Online: 18 January 2021

ABSTRACT

Landscapes, whose characters are the result of the action and interaction of natural and/or human factors, are dynamic. Proper understanding of today's landscapes is only possible through the knowledge of their historical dimension, in other words, changes that have occurred in timeslices or time-depth. Historic Landscape Characterization (HLC) is an approach to the management and understanding the present historic environment as a product of past changes and as the basis for future change.
HLC was applied to Kazdağı National Park which has very important ecosystems in terms of the future of Turkey especially Asia and Europe. In this research, Kazdağ 1 National Park Historic Landscape Character Types were mapped and relevant attributes were assigned them in 127 years of time depth with ArcGIS 10.1 software. HLC which was completed on the computer has been confirmed by field study and 'Direction of change', 'Rarity', 'Vulnerability' analysis was carried out. Finally, the relevant assessments were made in order to contribute protection, management and planning of National Park.

Keywords: Historic landscape characterization; Time depth; vulnerability; Rarity; direction of change; Kazdağı national park

(C) Ankara University, Faculty of Agriculture

\section{Introduction}

The concept of landscape first was defined as 'all the characteristics of a piece of land' about 200 years ago by the German geographer Alexander von Humboldt (1769-1859) (Antrop 2013).

In the case of the general provisions section of the European Landscape Convention, which opened for signature on 20.10.2000 and entered into force on 01.03.2004, the definition of landscape is '.... an area, as perceived by people, whose character is the result of the action and interaction of natural and/or human factors' (Council of Europe 2000). This definition has four aspects: (1) physical (an area), (2) holistic, (3) temporal (the result of the action and interaction of natural and/or human factors, developed through time), and (4) subjective-cultural (peoples' perceptions of the landscape) (Franch- Pardo et al. 2017).

Briefly, Landscape reflects the relationship between people and place. It is a product of the interaction of the natural, cultural, perceptual and aesthetic components of our environment (Tudor 2014). The changes that occur in this process have continuous and reached the dimensions that can cause the rapid loss of the characteristics of cultural landscapes with their different results (Antrop 2005; Tudor 2014).

According to European Landscape Convention, each member country is responsible 'to identify its own landscapes throughout its territory', 'to analyze their characteristics and the forces, pressures transforming them', and 'to take note of changes' (Council of Europe 2000). Landscape protection, management and planning as the three main tools are including in the European Landscape Convention, and in this context, various approaches have been developed to define the landscapes that is the basis of these processes.

Landscape Character Assessment (LCA) is one of these methods and an assessment technique originally developed in the 1990s in the UK to identify the combination of biophysical and socio-cultural elements that define a given landscape 
and distinguish it from others (Swanwick 2002; Tudor 2014; Franch-Pardo et al. 2017). Landscape character assessment is also a tool to help understand what the landscape is like today, how it has come to be like that, and how it may change in the future. In this context, The Landscape Character Analysis method outlines the necessity of knowledge of past landscapes in terms of shaping future landscapes in the light of understanding past landscape/historic landscape (Fairclough 2010).

The concept of historic landscape first was used by archaeologists who suggested the historic depths of modern landscapes to the planners and managers at the beginning of the 90s (Rippon \& Turner 1993; Rippon 2012).

In this context, a proper understanding of today's landscapes is only possible through the knowledge of their historic dimension and changes that have occurred in time-slices or time-depth. In other words, it is possible with the identifying and perception of historic landscapes (Sengur 2018). There are many techniques such as Landscape biography, Historic ecology, and Historic geography evaluating the perception of the landscape on the basis of landscape character in the scope of changes that occurred in a particular or long time. Also, Historic Landscape Character Analysis/Characterization (HLC) method approach which allows the comparison of today's landscape that we perceive with the values of the past with providing historic dimension to Landscape character analysis was developed by the Institute of English Heritage with the new name Institute of Historic England (Swanwick 2002; Aldred \& Fairclough 2003; Fairclough \& Macinnes 2003; Clark et al. 2004; Austin et al. 2007; Herring 2009). Program with the same purpose was named as Historic Land-use AssessmentHLA by the Institute of Historic Scotland in Scotland (Dixon et al. 1999; Fairclough \& Maccines 2003).

Historic Landscape Characterisation is a Geographic Information Systems (GIS) based approach defining visible historic landscape character that occurred in a time depth in the modern landscape, and a detailed analysis with the current status of the landscape can be performed. First in 1994, it was implemented as a 'Cornwall Historic Landscape Characterisation Project' in the Cornwall region by the Institute of Historic England with the support of Cornwall Council and the Countryside Commission. With this Project, the main principles of the method have been identified (Aldred \& Fairclough 2003; Winterburn 2008; Rippon 2012).

The development of the method has gained momentum with the implementation of similar areas as a region in the United Kingdom, Implementation of Historic Landscape Characterisation as a Programme was supported by the Institute of Historic England and local authorities. Several projects, especially for protected areas, have been developed, usually covering whole counties and occasionally extending beyond county boundaries (Aldred \& Fairclough 2003; Herlin \& Fairclough 2013). Historic Landscape Characterisation projects were applied to over $95 \%$ of United Kingdom.

International projects that were performed by academics and experts who are working on this topic in the United Kingdom and the Institute of Historic England have been effective in implementing and recognizing the historic landscape characterisation method in other countries. By defining historic landscape character types and areas in Silivri and its environment (Thrace region, Turkey), which is located to the east of the Mediterranean and The Island of Naxos (Aegean Sea, Greece), changes in rural landscape have been assessed in approximately 1500 years, including medieval and modern periods in two different areas with the research Project "Unlocking Historic Landscapes in the Eastern Mediterranean" within the scope of 'Landscape and Environment Programme', which was supported by the United Kingdom Art and Humanities Research Council in 2006-2007 (Crow \& Turner 2009; Crow \& Turner 2010; Crow et al. 2011).

In this research, HLC method approach which has been in accepted in general context and has application examples were implemented in Kazdağ 1 (Ida) National park which is one of the protected areas in Turkey with its natural, cultural, archeological and historical values. The method was conducted in a time depth of 127 years, covering 1890-1920, 19401970 and 2000-Present periods. The application of the HLC method, which is practiced in European countries, especially in the UK, to the protected area scale for the first time in Turkey is the original value of this research. In addition, the research is also important according to be one of the first works carried out using the HLC method.

\section{Material and Methods}

The research material is all the necessary materials related to the research method and the study area. We conducted the HLC method in Kazdağ (Ida) National Park which is located between 3941'25.00 "north latitude and 26 $6^{\circ} 55^{\prime} 34.55$ " east longitude in Balıkesir province, Edremit county (Figure 1). Kazdağı National Park has been selected as a research area with respect to its natural, cultural, historical and archaeological features and its protected area status.

Spatial and non-spatial data were used in the determination process of the Historic Landscape Characterization of the area. The other tools and equipment were also used to creation and evaluation of these data. The HLC method and other approaches in this context evaluate landscape from a long time to the present. However, the lack of a spatial database (historic maps or aerial photos) in our country makes the time depth more limited. So, the periodically varying materials were used in three different time periods with a time depth of 127 years. 



Figure 1- Location of Study Area

For the first period: Historic maps covering research area from 1890 to 1920 have been used as the main source. Among the maps of this period are H. Kiepert (1890) (1/250 000), V. Cuinet (1891) (1/500 000), R. Kiepert (1911) (1/400 000) and the Ottoman map (1919) (1/200 000).

For the second period: Topographical map (Edremit sheet) (1950) (1/200 000), Edremit-Çanakkale map (1944) (1/200 000) and the morphological map of Biga Peninsula Southwest Section (1/500 000) (1960) (Bilgin 1969) which cover the research area have been used as the main source. Also, (1953) (1/40 000) aerial photos with the roll number R 23 (108109-110-111-112-113-114), R-26 (116-117-118-119-120) and R-83 (188-189-190-191-192-193-194) have been investigated stereoscopically.

For the third period: For the 3 rd period which is covering the years from the 2000s to today, 1/25 000 scale topographic maps with sheet number I17d2, I17d3, I17c1, I17c2, I17c3, I17c4 have been used as the main source. Also, ArcGIS Basemap 2016 has been used as the current satellite image.

In addition to, Kazdağı National Park Management Plan and 1/50 000 scale Kazdağı National Park Natural and Cultural Values Map, 1/50 000 scale Tree Species Map and 1/50 000 Tree Age Class Map which produced under this plan are other sources benefited for three periods.

One of the Geographic Information System software ArcGIS 10.1 has been used in the process of creation and analysis of data sets, determination of historic landscape character types and analysis of the direction of change, vulnerability and rarity.

The 'Historic Landscape Characterization' process, which is carried out for the purpose and objectives of the research, consists of four phases. These steps are; Determination of historic landscape character types (Preparation of data set, Analysis of data set, Creation of polygons of historic landscape character types, Morphological analysis and assignment of historic landscape character types), Verification of historic landscape character types by field study, The analysis of direction of change, vulnerability and rarity and Overall evaluation.

In the process of determining the historic landscape characters, firstly the preparation and analysis of the data set have been carried out. During the preparation of data set, all the historic and modern maps periodically used in the research were geographically corrected with 0.00001 error rate using ArcGIS 10.1 software in a UTM (Universal Transverse Mercator) projection system and used as a baseline map during the creation of data layers. 
The most important stage of HLC is the identification of polygons as a historic landscape character type which reflects their common features from the past to today. There are basic historic landscape character types that are used commonly (Enclosed land, Unenclosed land, Woodland, Industrial land, Military, Ornamental and recreational areas, Settlements, Orchards, Communication, Water and valley floor) (Clark et al. 2003). Historic landscape character types are varied depending on the scope of work, situation of landscape and the aim of the analysis. So, we have determined the polygons as a common historic landscape character type as an Enclosed land (Open spaces with little/no vegetation, Woodland, Maquies, Agricultural areas) and Water bodies (River and canyon) in the Kazdağı National Park. In the definition process of polygons; each polygon must reflect the same historic landscape character type, pattern (regular or irregular) and dominant boundary morphology (straight, curved, variable). According to this, we have identified attributes that comprise the historic landscape character types and we have assigned these attributes to the polygons specified on the map as common historic landscape character types with ArcGIS 10.1. These attributes for Kazdağ National Park are Period, Area, Place name, Confidence, Landscape pattern, Boundary morphology, Endemic plant assets, Native plant assets, important plant assets, Monumental tree assets, Cultural Heritage assets and Archaeological Heritage assets. Thus, historic landscape character types have been identified for three periods and mapping studies have been completed.

Historic landscape character types obtained for the three-time period were confirmed by the field studies carried out with landscape architects, archaeologists and botanical experts in this process. In addition, evaluations of physical geography experts and knowledge of local people were also utilized during the study period.

The next stage of the study is analyses of the direction of change, rarity and vulnerability phase. Firstly, the direction of change analysis has been carried out in order to reveal how the landscape has developed and where or when the great threats and pressures occurred on the landscape. The evaluation of historic landscape character types at a specific time depth is an effective method to understand the continuity and stability of these character types. The analysis was carried out to measure the change in the process from the first period (1890-1920) to present day was carried out to give an indication of those HLC types which have decreased most rapidly, those which are stable and those which are increasing or new in the third period (present day). The direction of the change map obtained by comparing the $1^{\text {st }}$-period historic landscape character types map and $3^{\text {rd }}$-period historic landscape character types map. The difference in area was converted to a percentage and the scale of gain and loss defined in the following ranges: decreasing critically ( $>50 \%$ loss), decreasing rapidly (21-49\% loss), decreasing slowly (1-20\% loss), stable, increasing slowly (1-20\% gain), increasing rapidly (21-69\% gain), increasing significantly (>70\% gain), and new (Williams 2008).

In the second stage, rarity analysis has been conducted to determine whether historic landscape character types were common, frequent or rare. Rarity map obtained by calculating the total area of each HLC type as a percentage of the research area. All the HLC types have been assessed against each other according to the area that they cover to produce a scale of occurrence, or rarity. The area of each type was converted to a percentage and this figure plotted on a logarithmic scale in Excel. This enabled breaks and jumps in the range to be identified and six categories were developed: extremely rare $(<0.01 \%)$, very rare $(0.01-0.09 \%)$, rare $(0.1-0.3 \%)$, occasional $(0.35-1.0 \%)$, frequent $(1.0-5.8 \%)$, and common $(>5.9 \%)$ (Williams 2008).

Analysis of rarity and direction of change give information about the common historic landscape character types but cannot provide information about how these characters have changed and their vulnerabilities to future changes. However, the analysis of rarity and direction of change can be considered together to give a general idea about the determination of vulnerabilities (e.g. a rare and decreasing rapidly historic landscape character type will be highly vulnerable to change). The vulnerability of each historic landscape character type has been calculated using the direction of change and rarity scores. The logarithmic values of each have been added together to give a range of scores between 200 and minus 99 which have been divided into the ranges low (minus 99-1), medium (9-90), and high (100-200) (Williams 2008).

The river historic landscape character types were also included to analysis process and the areas affected by the rivers in the study area were determined by creating a $100 \mathrm{~m}$ buffer zone through ArcGIS 10.1 software (Mayer et al. 2005). According to the values mentioned above, the direction of change, vulnerability and rarity analysis of historic landscape character types of Kazdağı National Park have been carried out.

\section{Results}

As a result of the research, historic landscape character types maps of the three periods have been created. According to these maps, spatial distributions of historic landscape character types have been analyzed and the following results were obtained (Figure 2).

For the first period, as a woodland historic landscape character type, 1401 ha Pinus brutia-Quercus sp.-Pinus nigra, 1145 ha Pinus nigra-Abies equi trojani, 46 ha Pinus nigra woodland and as a maqui 45 ha Pinus brutia-Quercus sp. community which still exist today have been detected in Kazdağ National Park between 1890 and 1920. 
In the second period (1940-1970), 3083 ha Pinus brutia-Quercus sp.-Pinus nigra, 2132 ha Pinus nigra-Quercus sp., 1602 ha Pinus nigra-Quercus sp.-Castanea sp.- Abies equi trojani,543 ha Pinus nigra, 166 ha Pinus nigra-Pinus brutia, 151 ha Pinus nigra-Abies equi trojani, 101ha Pinus brutia have been detected as a woodland historic landscape character type. For maquis historic landscape character type, 150 ha Pinus brutia-Quercus sp. community have been determined. Also in this period, 273 ha Olive field has been detected as an agricultural area historic landscape character type. Besides this 656 ha canyon, 758 ha bare rock and 273 ha olive field historic landscape character type has been found.

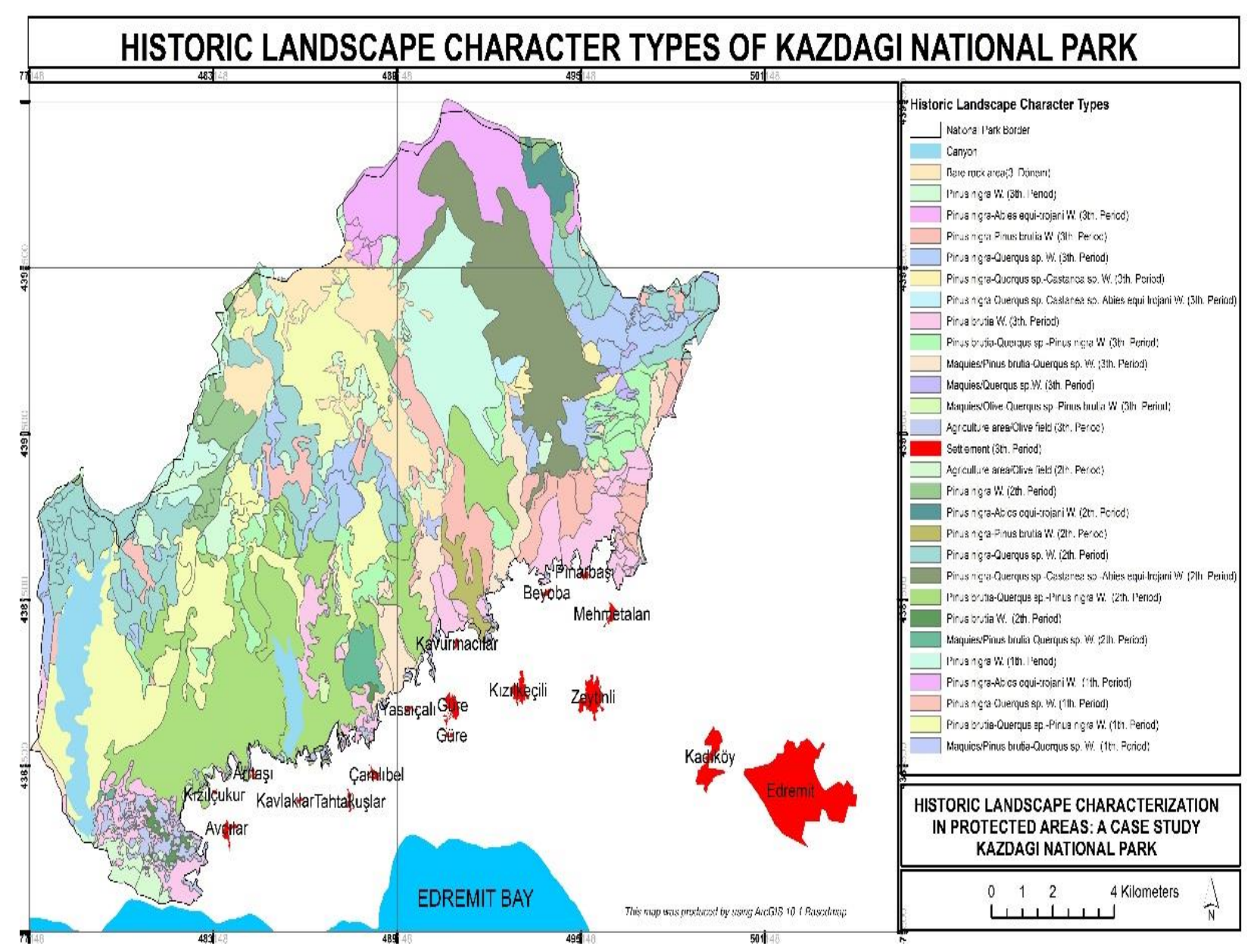

Figure 2- Historic Landscape Character Types Maps of Three Periods

Finally, in the third period (2000-present), 1223 ha Pinus brutia, 1077 ha Pinus nigra-Quercus sp., 814 ha Pinus brutia-Quercus sp.-Pinus nigra, 769 ha Pinus nigra, 675 ha Pinus nigra-Pinus brutia, 107 ha Pinus nigra-Abies equi trojani, 102 ha Pinus nigra-Quercus sp.-Castanea sp., 46 ha Pinus nigra-Quercus sp.-Castanea sp.-Abies equi trojani woodland historic landscape character type and 729 ha Pinus brutia-Quercus sp., 48 ha Quercus sp.,16 ha Olive-Quercus sp.-Pinus brutia maquis historic landscape character type, 506 ha olive field historic landscape character type, 1097 ha bare rock and 692 ha Canyon historic landscape character type have been determined. The area affected by water bodies for river historic landscape character type has been determined by creating a $100 \mathrm{~m}$ buffer zone in ArcGIS 10.1 . Periodically these values are for the first period 226 ha, second period 598 ha and the third period 575 ha. The canyon historic landscape character type for the water surface has been determined in the second and third periods and it could not be evaluated as spatial due to the inadequate scale of the maps in the first period.

The historic landscape characterization methodology identifies past landscapes spatially, as well as determines their perceptions and uses in the past with interpretations through information obtained from historic and antic sources. In this context, Kazdağı National Park Historic landscape character types have been assessed in terms of spatial analysis as well as their perceptions and characters in the past. After identifying the historic landscape character types and defining the perception, usage and characteristics of these landscapes in the past periods, the analysis of rarity and vulnerability was carried out and maps of rarity and vulnerability for three periods of the Kazdağ 1 National Park were obtained (Figures 3 and 4). 


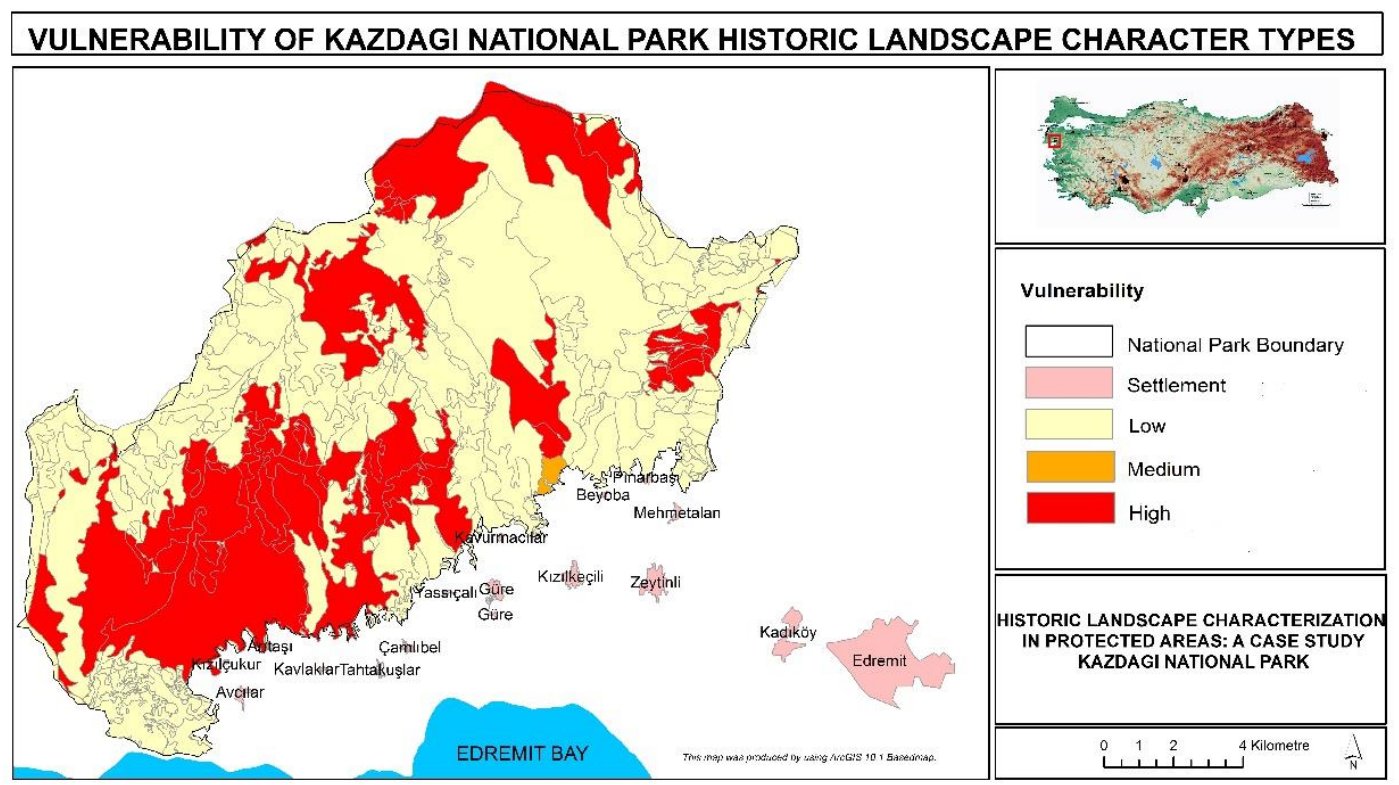

Figure 3- Vulnerability of Historic Landscape Character Types of Kazdağı National Park

\section{RARITY OF KAZDAGI NATIONAL PARK HISTORIC LANDSCAPE CHARACTER TYPES}

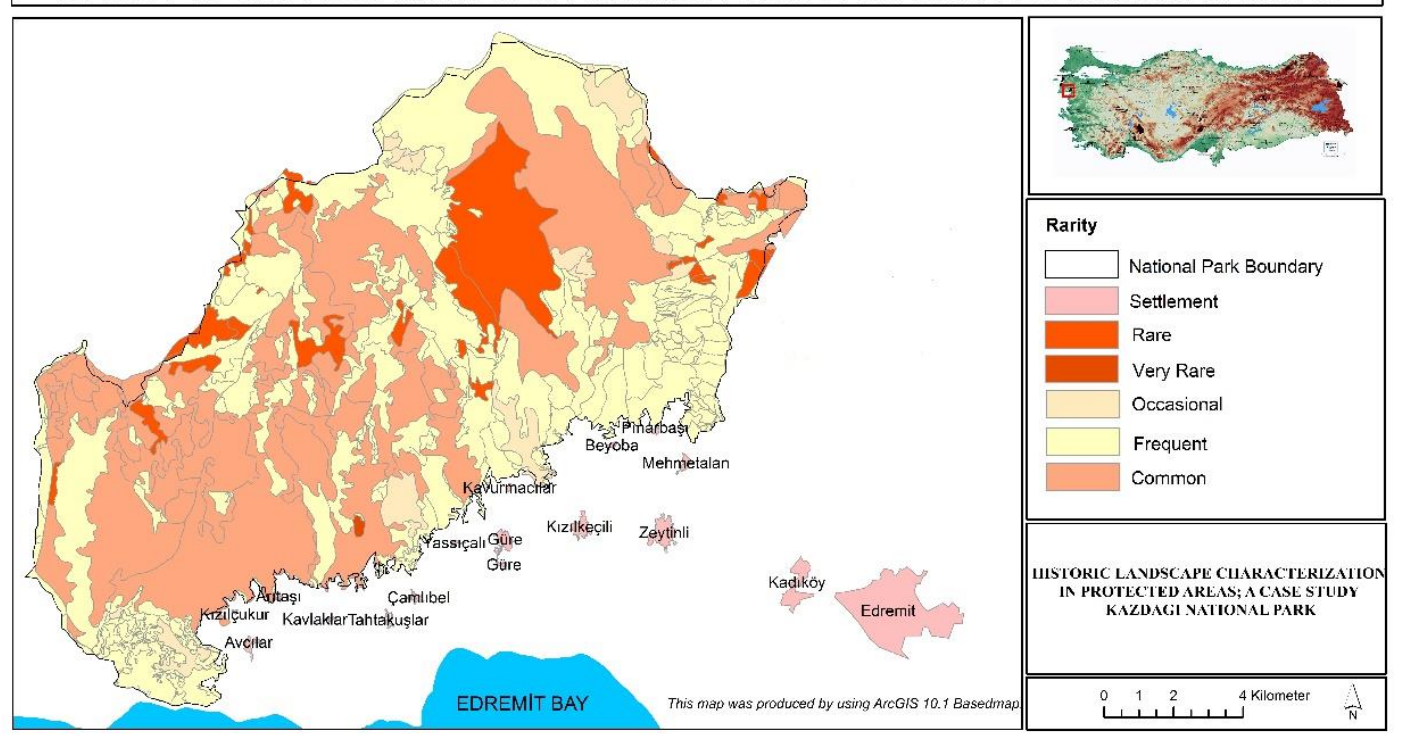

Figure 4- Rarity of Historic Landscape Character Types of Kazdağı National Park

When Kazdağ National Park is evaluated in this context, 13915 ha low, 55 ha medium and 8853 ha high fragile historic landscapes have been determined. The findings show that about $40 \%$ of the Kazdaği National Park has a high degree of vulnerability.

Increasing environmental problems and population, with changing economic conditions and consumption habits increase pressures that occur on the landscape. In this context, landscape management studies are becoming increasingly important (Sengur 2018).

There are four potential uses of historic landscape characterization: Landscape Management, Spatial Planning, Learning-Presentation (Research and Development Studies) and Landscape Character Analysis and Strategies (Clark et al. 2004).

Historic landscape characterization studies integrated with landscape character analysis will contribute development plans, long-term development plans, and environmental plans. It will also be a guide to many professional disciplines, such as landscape architects, urban and regional planners, architects and archaeologists. 
A key factor in securing the future of the National Parks' heritage is the statutory management plan each National Park Authority is required to produce. The protection and promotion of the historic environment is a key feature in these management plans, which address the implications of a wide variety of environmental pressures affecting the heritage (Tunnicliffe 2006).

With this study, an up to date database that provides information about the past and present landscape of the Kazdağları National Park has been created, and important information has been presented to the National Park Management Plan through the analysis studies performed.

In this context, The Historic landscape characterization method is GIS-based and uses classifications of landscape types or character types as attributes on which to base the analysis. It is fundamentally a subjective process and interpretative (by archaeologists with specialist skills) but uses actual data derived from cartographic and archaeological sources, allowing objectivity and transparency to be built into the characterization process. Also, one useful application of Historic landscape characterization is the creation of baseline data that are area based and comprehensive and which are used to measure, monitor and assess the impact of developments and changes to the (historic) landscape. This is important for cultural heritage and its role in the planning process (Aldred 2005). Another important contribution of The Historic landscape characterization studies revealing the historic values of the national parks is to enable people to understand the heritage values of national parks and to contribute to the protection and development of these areas by people.

The research area is largely natural area as well as its historic and cultural heritage value. In this context, one of the characteristic features of historic landscapes of Kazdağı National Park is the existence of endemic plants. In the study, the existence of endemic plants in the past periods has been revealed by using the books of Flora of Turkey Series by P. H. Davis. The method can be carried out with a much longer time relative to the purpose of the study, research area and sufficiency of the data to be used. In this context, researches about Historic landscape characterization carried out with a long time depth in natural areas should be evaluated more comprehensively, supported by the science of Palynology. With all these values and a 40\% fragility level, the Kazdağ 1 National Park is an internationally important region that needs to be quickly taken action in terms of management and protection of the landscape. According to Green (2009), there are four different management strategies for historic landscapes on a large scale. These; 'Conserve and Restore', 'Conserve', 'Selective Conservation' and 'Mitigate or Restore'. According to its vulnerability level, Kazdağı National Park should be evaluated in the 'Conserve and Restore' (historic landscapes of medium to high significance which have declined rapidly or critically. Surviving examples of these landscapes need protection whilst opportunities and projects to restore significant lost sites would be desirable in most instances.) must be protected with a new system. According to Sengur (2010), the Kazdağları Region has been evaluated as a World Heritage, and it was determined that it has similar characteristics with the $6^{\text {th }}, 7^{\text {th }}, 9^{\text {th }}$, and $10^{\text {th }}$ criteria of UNESCO World Heritage. The findings of the research support this finding. The value of resources in our globalizing world has been exceeded the limits such as region or country, this situation has brought the need for international responsibility and protection.

\section{Acknowledgements}

This study is an output of doctoral thesis carried out in 2011-2017 with the name of 'Historic Landscape Character Analysis in Protected Areas; A Case Study Kazdağı National Park'. The research was supported by the '1002- Short Term R\&D Funding Program (TUBITAK-1160694) with ' Identifying and Mapping of Historic Landscape Characters in Kazdağı National Park' Project. In this context, the authors would like to thank to TUBITAK (The Scientific and Technological Research Council of Turkey).

The authors are very grateful to Assoc. Prof. Yasemin Polat who is a researcher in the TUBITAK-116O694- ' Identifying and Mapping of Historic Landscape Characters in Kazdağı National Park’ Project.

The authors express their thanks to Prof. Dr. Sam Turner for the invitation of the workshop "Characterising Historic Landscapes: Interdisciplinary Perspectives", which was held in İzmir, Turkey on March 1-4 ${ }^{\text {th }} 2016$. The workshop was supported by Scientific and Technical Research Council of Turkey (TUBITAK) and the British Council, as a part of Katip Çelebi Newton Fund and organized by Newcastle University and Ege University.

\section{References}

Aldred O \& Fairclough G (2003). Historic Landscape Characterisation: taking stock of the method. English Heritage/Somerset County Council, London. Aldred O 2005. Identifying and Assessing Landscape through Historic Landscape Characterisation, Proceedings of the Effects of Afforestation on Ecosystems, Landscape and Rural Development Conference (AFFORNORD), Reykholt, Iceland pp. 227-234

Antrop M (2005). Why landscapes of the past are important for the future. Landscape and Urban Planning 70(1-2): 21-34

Antrop M (2013). A Brief History of Landscape Research. In: P Howard, I Thompson, E Waterton (Eds.), The Routledge Companion to Landscape Studies. London and New York: The Routledge Companions pp. 12-23

Austin D, Rippon S \& Stamper P (2007). Landscapes, 8 (ii) (Macclesfield). 
Bilgin T (1969). Geomorphology of Southwestern part of Biga Peninsula. Istanbul Univ. Publ. No: 1433. Geography Inst. Publ 55

Clark J, Darlington J \& Fairclough G J (2003). Pathways to Europe's landscape: European pathways to the cultural landscape, 2000-2003. EPLC

Clark J, Darlington J \& Fairclough G J (2004). Using Historic Landscape Characterisation: English Heritage's Review of HLC; Applications 2002-03. English Heritage and Lancashire County Council

Council of Europe (2000). European Landscape Convention.-European Treaty Series No. 176

Crow J \& Turner S (2009). Silivri and the Thracian hinterland of Istanbul: An historic landscape. Journal of the Anatolian Studies 59: 167-181 pp

Crow J \& Turner S (2010). Unlocking historic landscapes in the Eastern Mediterranean: two pilot studies using historic landscape characterisation. Journal of the Antiquity 84: 216-229 pp.

Crow J, Turner S \& Vionis A K (2011). Characterizing the historic landscapes of Naxos. Journal of the Mediterranean Archaeology 24(1): 111-137 pp

Cuinet V (1894). La Turquie d'Asie: géographie administrative, statistique, descriptive et raisonnée de chaque province de l'Asie Mineure. E. Leroux

Dixon P, Dyson-Bruce L \& Stevenson J (1999). Historic Land-use Assessment (HLA): Development and Potential of a Technique for Assessing Historic Landscape Patterns, Report of the Pilot Project 1996-98, Edinburgh: Historic Scotland/RCHMS

Fairclough G \& Macinnes L (2003). Landscape character assessment guidance for England and Scotland. Topic paper 5: Understanding historic landscape character. Scottish Natural Heritage and The Countryside Agency, Edinburgh

Franch-Pardo I, Napoletano M, Gerardo B, Barrasa S \& Pomar L (2017). The Role of Geographical Landscape Studies for Sustainable Territorial Planning. Sustainability 9(11): 2123

Green D (2009). 'Chilterns Historic Landscape Characterisation Project', Final Report, Buckhinghampshire County Council and English Heritage

Herlin I S \& Fairclough G (2013). Methods: Scales and Levels, Workshop 1: Identify, Analyse, Characterise the Landscape to Act, Improve the Knowledge, Montenegro $8 \mathrm{p}$

Herring P C (2009). Framing perceptions of the historic landscape: historic landscape characterization (HLC) and historic land-use assessment (HLA). Scottish Geographical Journal 125(1): 61-77

HGK- (General Command of Mapping) (1950). Topographic map (Edremit sheet), 1/200.000. Ankara

HGK-(General Command of Mapping) (2000). Topographic maps with map numbers: I17d2, I17d3, I17c1, I17c2, I17c3, I17c4., 1/25.000. Ankara

Kiepert H (1890). Specialkarte vom westlichen Kleinasien: nach seinen eigenen Reisen und anderen grösstenteils noch unveröffentlichten Routenaufnahmen bearbeitet. Verlag von Dietrich Reimer

Kiepert R (1902). Karte von Kleinasien in 24 blatt. Dietrich Reimer. Lionel Pincus and Princess Firyal Map Division, The New York Public Library. (1902 - 1916). Karte von Kleinasien in 24 Blatt. Massstab 1:400,000. Bearbeitet von Dr. Richard Kiepert. Berlin Dietrich Reimer (Ernst Vohsen). 19041907. Retrieved from https://digitalcollections.nypl.org/items/95d1a99c-80d6-c2f1-e040-e00a18064f41

Mayer P, Reynolds S \& Canfield T (2005). US Environmental Protection Riparian Buffer Width, Vegetative Cover, and Nitrogen Removal Effectiveness: A Review of Current Science and Regulations. EPA/600/R-05/118. Cincinnati, OH: US Environmental Protection Agency EPA

Rippon S \& Turner R (1993). The Gwent Levels Historic Landscape Study. Archaeology in the Severn Estuary 1993: 113-117

Rippon S (2012). Making sense of a historic landscape. Oxford University Press on Demand

Sengur S (2018). A New Method Approach in the Analysis of the Landscape: Historic Landscape Characterisation. In: H Arapgirlioğlu, A Atik, S Hızıroğlu R L Elliott \& D Atik (Eds.), The Most Recent Studies in Science and Art, Gece Publishing, Ankara-Turkey pp. 875-885

Swanwick C (2002). Recent Practice and the Evolution of Landscape Character Assessment: Topic Paper 1. The Countryside Agency and Scottish Natural Heritage

Tunnicliffe S (2006). A Landscape Legacy: National Parks and the historic environment. Historic England and the Countryside Agency, England

Tudor C (2014). An approach to landscape character assessment. Natural England

Williams L (2008). Northumberland Historic Landscape Characterisation. Northumberland County Council

Winterburn E (2008). Historic landscape characterization in context. Journal of the FORUM E Journal 8: 33-46 pp Newcastle University 